\title{
Verbal Working Memory and Verbal Memory's Relationship to Discourse Comprehension in Healthy Elderly
}

\author{
Hyunjoo Choi \\ Department of Communication Disorders, Korea Nazarene University, Cheonan, Korea
}

Correspondence: Hyunjoo Choi, $\mathrm{PhD}$ Department of Communication Disorders, Korea Nazarene University, 48 Wolbong-ro, Seobuk-gu, Cheonan 331-718, Korea Tel: + 82-41-570-1677 Fax: + 82-41-570-7846 E-mail: hjchoi@kornu.ac.kr

Received: May 31, 2014

Revised: July 17, 2014

Accepted: August 14, 2014

This research was supported by the Korea Nazarene University Research Grants 2014.

\begin{abstract}
Objectives: Comprehension of spoken discourse is an important component of functional communication in the elderly and is related to various cognitive processes. The purpose of the present study was to identify the characteristics of discourse comprehension in healthy elderly adults and see how discourse comprehension is influenced by both verbal working memory and verbal memory. Methods: Sixty healthy elderly adults (male 30, female 30) participated in this study. They took part in discourse comprehension tasks using two different stories, a verbal working memory test (Digit Span Test: Forward/Backward) and a verbal memory test (Seoul Verbal Learning Test [SVLT]). Results: The results were as follows. First, discourse comprehension ability did not vary with gender, age, educational level or Korean Mini-Mental State Examination score. Second, there was a significant correlation between the discourse comprehension score and performance on the Backward Digit Span Test and all sections of the SVLT. Third, regression analysis indicated that verbal working memory and verbal memory were significant predictors for discourse comprehension ability in healthy elderly. Conclusion: These results suggest that discourse comprehension ability is a complex skill that depends largely on different aspects of verbal memory. These finding have clinical implications for evaluation and intervention in discourse comprehension for elderly patients with neurogenic communication disorders.
\end{abstract}

Keywords: Discourse comprehension, Verbal working memory, Verbal memory 노화(aging)는 다양한 인지기능의 변화를 초래하며, 이와 관련 된 연구는 급속한 인구의 고령화로 인해 최근에 각광받는 분야이 다. 정상적인 노화로 나타나는 인지기능 저하를 설명하는 인지 이 론들은 최근 20년 동안 활발히 연구되어 왔다(Thornton \& Light, 2006). 이러한 연구들은 노화로 인한 인지기능 저하의 원인을 인지 처리 속도의 저하(Salthouse, 1996), 정보를 저장하고 조작하는 작 업기억(working memory) 능력의 저하(Carpenter, Miyake, \& Just, 1994), 목적과 관련 없는 정보를 비활성화시키는 억제(inhibition) 기제의 손상(Zacks \& Hasher, 1997), 신경흥분전달 연결의 손상 (Burke, MacKay, \& James, 2000) 및 감각 손상(Baltes \& Lindenberger, 1997) 등으로 설명하고 있다. 인지기능 변화와 함께 언어 및 의사소통 능력도 제한을 보이는데 이러한 언어처리 능력의 제한은 효과적인 의사소통을 방해하여 고령자의 사회적 상호작용 및 심리
적 안정에 부정적인 영향을 준다(Hummert Garstka, Ryan, \& Bonnesen, 2004).

고령자의 담화 산출과 이해 과제는 일상생활에서의 의사소통 능 력을 실제적으로 반영하기 때문에 정보전달의 효율성, 의사소통의 적절성 등을 평가할 수 있다. 최근 고령자의 통합적인 의사소통 능 력을 살펴보기 위한 담화 과제의 사용이 증가하는 추세이나 담화 의 산출에 보다 초점이 맞춰져 있으며 담화 이해와 관련된 연구는 상대적으로 제한적이다(Welland, Lubinski, \& Higginbotham, 2002).

담화 이해는 개별 단어와 문장을 순차적으로 이해하는 것 이상 의 활동을 요구한다. 담화 이해 능력은 단어, 구, 문장 사이의 의미 적, 구문적 관계를 파악하는 것으로 담화의 논리적이고 의미적인 표상을 구조화하는 것을 요구한다(Daneman \& Merikle, 1996). 또 한, 담화 이해 능력은 이전 지식과 현재의 입력(input) 내용을 통합 
하는 능력을 필요로 하는데, 이는 단순한 언어처리 능력 이상의 정 신적인 표상(representation)을 포함한다(Thornton \& Light, 2006). 따라서, 담화 이해는 그 처리과정과 표상에서 여러 단계를 거친다. 연구자들은 이러한 단계를 표면 구조(surface structure), 명제적 추 상성(propositional abstraction), 상황 모형(situation model)으로 구분하여 설명하였다(Radvansky \& Curiel, 1998; Sparks \& Rapp, 2010). 표면 구조란 담화 내 정보에서 사용된 실제 단어나 구문유형 및 구조 자체에 해당되는 텍스트 기반 처리과정을 의미한다. 다음 으로 명제적 추상성 역시 텍스트 기반(text base) 처리과정으로 실 제 담화 안의 구체적인 내용을 포함하지만 문장 형태나 어휘의 동 일성은 중요하지 않은 구조이다(예를 들어 '그녀가 문을 열었다'와 '문은 그녀에 의해 열렸다'는 다른 표면 구조이지만 동일한 명제적 추상성을 가짐). 마지막으로 상황 모형은 심성 모형(mental model) 이라고도 하며, 담화 내용과 관련된 정보를 포함하기 때문에 해당 담화 자체의 이해뿐 아니라 이전 지식이나 장기기억(long term memory)과의 통합 능력을 강조한다. 이렇듯 고령자의 담화 이해 능력 은 단편적인 언어 능력이나 기억 능력만으로 설명할 수 없으며, 다 양한 인지기능 이론 및 언어 이론들을 통해 종합적으로 이해되어 야 한다(Burke et al., 2000). 따라서 개별적인 변인이 담화 이해 능력 에 미치는 영향은 제한적이다. 이와 관련하여, Caplan과 Evans (1990)는 일반 고령자의 담화 이해 능력은 단어 이해 및 문장 이해 력과 유의한 상관을 보이지 않는다고 하였으며, 고령자의 연령, 교 육 정도, 성별 등의 영향 또한 제한적인 것으로 알려져 있다(Ferstl Walther, Guthke, \& von Cramon, 2005; Mackenzie, 2000).

다양한 인지기능 중 기억 능력은 고령자의 언어 수행 능력을 설 명하는 중요한 요인으로, 특히 언어 이해 능력과 밀접한 관련성을 가진다(Bowles \& Poon, 1985). 전통적으로 많은 이론들은 단기기 억(short term memory) 용량이 청각적 이해력에 결정적인 영향을 미친다고 주장한다(Just \& Carpenter, 1980). 즉, 일시적인 저장 능 력(temporary storage)은 성공적인 언어 이해에 중요한 요소이므로 짧은 저장 능력을 가진 사람의 경우 자신이 들은 내용을 기억으로 활성화시키는 능력이 제한되어 담화의 연속적인 개념(idea)을 통합 하지 못한다(Daneman \& Merikle, 1996). 그러나, 일부 연구자들은 인지기능 장애가 없는 일반 성인의 경우 단기기억 용량과 담화 이 해 능력 간에는 매우 낮은 상관만을 보인다고 주장한다(Daneman \& Carpenter, 1980; Ferstl et al., 2005; Perfetti \& Goldman, 1976). 이러한 역설적인 결과는 단기기억을 수동적인 저장 완충기로 취급 하는 전통적인 단기기억 검사 이론과 관련이 있다. Daneman과 Carpenter (1980)는 단순한 폭 검사(span test)로 대표되는 전통적 인 기억 검사는 입력(input), 약호화(encoding), 인출(retrieve) 시킬
수 있는 최대한의 항목수(item)로 측정하도록 되어있는데, 이러한 검사로는 담화 이해와 기억과의 관련성을 설명해내지 못한다고 주 장한다. Daneman과 Carpenter (1980)는 담화 이해와 관련된 기억 능력으로 '제한된 저장 능력을 최대한 활용하려는 처리과정'인 기 능적 기억용량을 제안하였으며, 이를 작업기억(working memory) (Baddeley, 1986)으로 설명하였다. 작업기억 능력은 언어 이해, 특히 담화 이해에 핵심적인 역할을 하는 것으로 알려져 있다. 작업기억 은 저장기능(storage function)과 함께 처리기능(processing function)을 강조한다. 이러한 작업기억 능력 중 주로 단기기억(short term memory)을 요구하는 저장기능은 청각적으로 입력된 단어, 구, 문장을 기억하는 능력과 관련이 있으며, 처리기능은 구문을 분 석하고, 담화 안의 세부 의미를 연결하고, 각각의 의미를 통합하는 능력과 관련이 있다(Just \& Carpenter, 1987). 이와 관련하여 Water 와 Caplan (2005)은 인지기능장애가 없는 일반 고령자에게서 경우 저장 기능이 강조되는 개별 문장 이해 능력 자체는 작업기억과는 큰 상관이 없으나 저장기능과 처리기능 모두를 요구하는 담화 이해 능력은 작업기억의 처리용량과 밀접한 관련이 있음을 보고하였다. 또한, Norman, Kemper, Kynette, Hintat과 Anagnopoulous (1991) 는 담화 이해 능력과 숫자 외우기 검사(Digit Span Test)를 통한 작 업기억 능력과의 상관을 연구하였는데, 그 결과 저장기능을 강조하 는 숫자 바로 따라 외우기(Digit Span Test: Forward) 점수는 담화 이해 능력과 유의한 상관이 나타나지 않았지만, 저장기능과 처리기 능을 함께 강조하는 숫자 거꾸로 따라 외우기(Digit Span Test: Backward) 점수는 담화 이해 능력과 밀접한 관련이 있다고 주장하였다. 따라서 고령자의 담화 이해 능력 저하는 담화의 일차적인 의미를 등록함과 동시에 담화의 내용을 통합하고 구조화하는데 요구되는 처리용량의 제한을 반영한다(Cohen, 1979; Ferstl et al., 2005). 이와 같이 담화 이해 능력은 단기기억, 작업기억, 장기기억 모두를 포함한 통합적인 기억능력과 관련을 가진다(Trabasso \& Magliano, 1996).

담화 이해 능력은 이미 설명했듯이 고령자의 통합적인 의사소통 과 깊은 연관이 있음에도 불구하고 담화와 관련된 기존의 연구들 은 담화 산출과 관련된 연구에 집중되어 있다. 또한, 고령자를 대상 으로 한 대부분의 담화 이해 연구는 읽기 과제(reading test)를 사 용하였고, 예-아니오 질문으로 구성된 재인(recognition) 문항으로 평가되기 때문에 실제적인 구어적 의사소통 상황에서의 담화 이해 능력을 반영하기에는 한계를 가진다. 실제적인 의사소통 상황에서 의 담화 이해는 상대방의 이야기를 듣고 들은 내용에 대해 재인하 는 능력뿐 아니라 회상(recall)하는 능력 또한 요구한다. 따라서 청 각적으로 담화를 제시하고 간단한 질문에 답하도록 하는 회상 과 제의 사용이 실제적인 이해적 측면에서의 의사소통 능력을 보다 
잘 반영할 것으로 여겨진다. 일부 아동을 대상으로 한 담화 이해 과 제의 경우 담화를 듣고 다양한 질문에 답하도록 하는 회상 과제들 이 사용되고 있으며, 이러한 과제의 사용은 아동의 담화 이해 능력 을 보다 심층적으로 평가할 수 있는 척도로 사용된다(Cain \& Oakhill, 1999; Norbury \& Bishop, 2002; Yun \& Kim, 2005). 담화를 듣 고 네-아니오로 대답해야하는 재인 과제에 비해 구어로 적절한 대 답을 요구하는 회상 과제의 경우 들은 이야기의 내용을 저장하고, 회상을 통해 대답해야하기 때문에 단기기억 및 장기기억의 부담이 가중될 수 있어 회상 능력을 평가하는 언어기억과의 관련성 또한 살펴볼 필요가 있다. 그러나 고령자를 대상으로 구어적 회상 과제 를 사용한 담화 이해 연구는 대단히 제한적이며, 이러한 과제의 수 행이 다양한 기억 능력과 어떠한 관련이 있는지에 관한 연구는 거 의 없는 실정이다. 따라서 본 연구는 일반 고령자를 대상으로 이야 기를 듣고 해당 질문에 답하는 담화 이해 과제를 사용하여 성별, 연 령, 교육 정도 및 K-MMSE 점수에 의한 영향을 살펴보고, 담화 이 해 능력과 구어 작업기억 및 언어기억의 상관을 알아보는 것을 목 적으로 하였다.

\section{연구 방법}

\section{연구 대상}

본 연구의 대상은 65 세 이상 85 세 이하의 일반 고령자 60 명으로, 성별에 의한 언어 능력의 차이(Borod, Goodglass, \& Kaplan, 1980) 를 고려하여 성비를 통제하였다(남성 30명, 여성 30명). 일반 고령자 의 구체적인 선정기준은 다음과 같다. (1) 한국판간이정신상태검사 (Korean Mini-Mental State Examination, K-MMSE: Kang, 2006) 점수가 정상 범주(해당 연령과 교육년수 규준에서 $16 \%$ ile 이상)에 속하며, (2) 인지기능에 영향을 미치는 정신적, 신경학적 질환의 경 험이 없고, (3) 과제를 수행하고 지시를 따르는데 요구되는 시청각 능력을 가지고 있어야 한다. 선정된 연구 대상자의 연령, 교육년수 및 K-MMSE 점수의 기술통계치를 Table 1에 제시하였다. 성별에 따른 연령, 교육년수 및 K-MMSE 점수의 차이가 있는지 알아보기
위하여 독립표본 $t$-검정을 실시한 결과, 연령과 K-MMSE 점수에서 는 성별에 따른 차이가 없었지만, 교육년수의 경우 남성이 여성에 비해 유의하게 높은 것으로 나타났다 $(t=2.761, p<.05)$.

\section{연구 과제}

담화 이해 자료

담화 이해 과제로 본 연구에서는 Choi와 Choi (2013)에서 사용 된 이야기 이해 과제를 사용하였다. 본 이야기 이해 과제는 성인에 게 친숙한 식당과 돌잔치 스크립트를 활용한 ‘복날'과 ‘돌잔치' 두 개의 이야기로 33 문장, 200 단어, 428 음절로 구성되어 있다. 또한, 이 야기 문법의 하위 범주인 배경, 계기사건, 내적 반응, 시도, 결과, 반 응이 모두 포함되어 있다. 이야기는 청각적으로 제시하였으며 이야 기 내용에 관한 질문에 간단히 답하도록 하였다. 이야기 이해 과제 는 3 가지의 질문유형 8 개씩으로 구성된 24 개의 질문으로 이루어져 있으며, 담화 이해 과제의 질문유형은 기존의 연구(Cain \& Oakhill, 1999; Norbury \& Bishop, 2002)를 따랐다. 본 연구에서 사용된 질문유형은 이야기의 내용 중 표면적으로 드러난 사실적 정보 이 해(literal/factual information)', 문법적인 연결장치(cohesive devices)의 의미를 텍스트 연결 관계에 따라 이해해야 하는 '텍스트 연결 추론(text-connecting inference)', 이야기의 의미를 청자의 지식과 통합하여 추론해야 하는 '빠진 정보 추론(gap-filling inference)'이 었다. 질문유형의 예는 Appendix 1에 제시하였다. 또한, 이야기를 제시하는 동안 고령자의 집중력을 유지시키기 위하여 이야기의 전 개에 따라 1-4문장 당 한 장씩, 총 10장의 삽화를 함께 제시하였다. 이야기 이해 과제의 채점 기준은 '적절한 대답(2점)'과 '불완전하나 적절한 대답(1점)'(예, 경로당 $\rightarrow$ 노인정), '부적절한 대답(0점)'으로 구분하였으며, 2 가지 이야기 점수를 합산하여 사용하였다. 담화 이 해 점수는 이야기 당 24 점씩 총점 48 점이었다.

\section{구어 작업기억 검사}

본 연구에서는 구어 작업기억을 평가하기 위하여 숫자 외우기 검 사(Digit Span Test; Kang, Chin, \& Na, 2002)를 사용하였다. 숫자

Table 1. Characteristics of subjects

\begin{tabular}{|c|c|c|c|c|c|c|c|c|}
\hline & \multicolumn{5}{|c|}{ Age level } & \multirow{2}{*}{ Age } & \multirow{2}{*}{ Education } & \multirow{2}{*}{ K-MMSE } \\
\hline & $65-70$ & $71-75$ & $76-80$ & $80-85$ & Total & & & \\
\hline Male & 9 & 6 & 9 & 6 & 30 & $75.10(6.06)$ & $11.37(4.12)$ & $26.56(1.72)$ \\
\hline Female & 9 & 9 & 6 & 6 & 30 & $73.97(5.76)$ & $8.10(5.00)$ & $26.97(1.56)$ \\
\hline Total & 18 & 15 & 15 & 12 & 60 & $74.53(5.90)$ & $9.73(4.83)$ & $26.76(1.64)$ \\
\hline
\end{tabular}

Values are presented as number or mean (SD).

K-MMSE $=$ Korean Mini-Mental State Examination. 
외우기 검사는 주의력(attention)과 음운루프(phonological loop) 를 이용한 구어 작업기억을 평가하는 대표적인 도구이며(Baddeley \& Hitch, 1974), 숫자 바로 따라 외우기(Digit Span Test: Forward) 와 숫자 거꾸로 따라 외우기(Digit Span Test: Backward)로 구성되 어 있다. 숫자 바로 따라 외우기는 3-9개의 숫자를 초당 하나씩 불 러주고 그대로 따라 말하게 하는 검사로 1 차에서 실패할 경우 2 차 까지 검사를 시행할 수 있으며, 정확히 따라 말한 숫자의 단계를 점 수로9점 만점으로 채점한다. 숫자 거꾸로 따라 외우기는 숫자 바로 따라 외우기와 유사한 방식으로 일련의 숫자를 듣고 역순으로 말 하는 과제로 2-8개의 숫자까지 8점 만점으로 채점한다.

\section{언어기억 검사}

본 연구에서 언어기억을 평가하기 위하여 우리나라에서 표준화 된 서울언어학습검사(Seoul Verbal Learning Test, SVLT; Kang \& $\mathrm{Na}, 2003)$ 를 사용하였다. SVLT는 즉각회상(immediate recalls), 지 연회상(delayed recalls) 및 재인(recognition) 검사로 구성되어 있 다. SVLT의 검사 단어는 꽃, 주방기구, 문구 범주의 범주당 4단어 총 12 단어로 구성되어 있다. 즉각회상은 2 초에 하나씩 12 개의 단어 를 불러주고 기억나는 단어를 말하도록 하는 과제로 3 번 시행하여 총 36 점 만점으로 채점한다. 다음으로 지연회상 검사는 3 차 즉각회 상 시행이 끝난 후 20 분 이후에 기억나는 단어를 회상하여 말하도 록 하는 검사로 12 점 만점으로 채점한다. 지연회상 검사 이후에는 대상자에게 단어를 불러주고 해당 단어가 검사 단어에 있었는지 없었는지를 묻는 재인 검사를 실시한다. 대상자의 반응을 정반응 (true positive, TP)과 오반응(false positive, $\mathrm{FP}$ )으로 나누어 기입하 고 $(\mathrm{O}, \mathrm{X})$, 정반응 $(\mathrm{TP})$ 과 정부정(true negative $=12-\mathrm{FP})$ 을 더한 재인 점수를 24점 만점으로 계산한다.

\section{연구절차}

모든 검사는 연구자와 대상자가 일대일로 조용한 곳에서 진행하 였으며, 대상자의 모든 반응은 녹음하였다. 이야기 이해 과제는 Choi와 Choi (2013)의 검사 절차에 따라 삽화를 제시하며 자연스 러운 말속도로 이야기를 들려주고 대상자에게 구체적인 대답을 유 도하였다. 숫자 외우기 검사와 SVLT는 표준화된 절차에 따라 검사

Table 2. Correlations among age, education, K-MMSE scores and discourse comprehension scores

\begin{tabular}{llccc}
\hline & Gender & Age & Education & K-MMSE \\
\hline Discourse compre- & Male & -.176 & .206 & .212 \\
hension & Female & -.248 & .313 & .335 \\
\hline
\end{tabular}

K-MMSE=Korean Mini-Mental State Examination.
를 진행하였다.

\section{통계분석}

본 연구의 통계처리는 PASW version 18.0 (SPSS Inc., Chicago, IL, USA) 프로그램을 사용하였다. 우선, 담화 이해 점수에서 성별 에 따른 차이가 있는지 알아보기 위하여 교육년수를 공변량으로 한 공변량분석을 실시하고, 성별에 따라 담화 이해 점수가 연령이 나 교육년수 및 K-MMSE 점수에 상관이 있는지 알아보기 위하여 상관분석을 실시하였다. 다음으로 담화 이해 능력과 구어 작업기 억 및 언어기억 검사 점수와의 상관을 알아보기 위하여 교육년수 를 제어변수로 하여 담화 이해 점수, 숫자 바로 따라 외우기 점수, 숫자 거꾸로 따라 외우기 점수, SVLT 즉각회상, 지연회상, 재인점수 와의 편상관계수를 산출하였다. 마지막으로 담화 이해 점수에 영 향을 미치는 구어 작업기억 및 언어기억의 영향을 알아보기 위하 여 중다회귀분석을 실시하였다.

\section{연구 결과}

\section{성별에 따른 담화 이해 점수와 연령, 교육년수 및 K-MMSE 점수의 상관}

담화 이해 점수의 성별에 따른 차이가 있는지 알아보기 위하여 교육년수를 공변량으로 한 공변량분석을 실시한 결과 성별에 따른 담화 이해 점수의 차이는 나타나지 않았다 $(F=2.481, p>.05)$. 다음 으로 성별에 따라 담화 이해 점수가 연령이나 교육년수 및 K-MMSE 점수에 상관이 있는지 알아보기 위하여 상관분석을 실시하였다 (Table 2). 그 결과 남성과 여성 모두 담화 이해 점수와 연령, 교육년 수, K-MMSE 점수의 상관은 유의하지 않았다.

\section{담화 이해 점수, 구어 작업기억 및 언어기억의 기술통계 및 상관}

담화 이해 점수와 구어 작업기억 및 언어기억의 기술통계치를

Table 3. Descriptive statistics for discourse comprehension, verbal working memory, and verbal memory

\begin{tabular}{lcc}
\hline Task & Mean & SD \\
\hline Discourse comprehension & 32.58 & 5.25 \\
Digit span & & \\
Forward & 5.83 & 1.62 \\
Backward & 3.61 & 1.26 \\
SVLT & & \\
Immediate recalls & 16.72 & 5.74 \\
Delayed recalls & 4.50 & 2.83 \\
Recognition score & 19.25 & 2.49 \\
\hline
\end{tabular}

SVLT = Seoul Verbal Learning Test (Kang \& Na, 2003) 
Table 4. Partial correlations among discourse comprehension scores, verbal working memory and verbal memory

\begin{tabular}{|c|c|c|c|c|c|c|}
\hline & Discourse comprehension & DF & $\mathrm{DB}$ & Immediate recalls & Delayed recalls & Recognition score \\
\hline Discourse comprehension & 1 & - & - & - & - & - \\
\hline DF & .148 & 1 & - & - & - & - \\
\hline $\mathrm{DB}$ & $.290^{*}$ & $.329^{*}$ & 1 & - & - & - \\
\hline Immediate recalls & $.339^{*}$ & .060 & $.292^{*}$ & 1 & - & - \\
\hline Delayed recalls & $.409^{* *}$ & .096 & .231 & $.764^{* *}$ & 1 & - \\
\hline Recognition score & $.510^{* *}$ & .088 & $.306^{*}$ & $.544^{* *}$ & $.503^{* *}$ & 1 \\
\hline
\end{tabular}

DF= Digit Span Forward; DB= Digit Span Backward.

${ }^{*} p<.05,{ }^{* *} p<.001$.

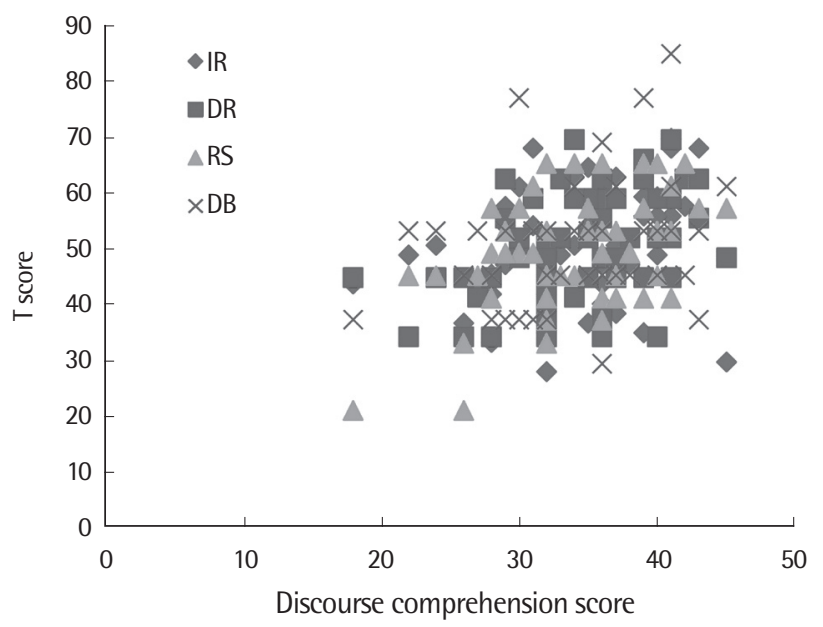

Figure 1. The scatter plot of $\mathrm{T}$ scores of memory tasks and discourse comprehension scores. $\mathrm{IR}=\mathrm{Immediate}$ recalls; $\mathrm{DR}=$ delayed recalls; $\mathrm{RS}=$ recognition score; DB= Digit Span Backward.

Table 3에, 교육년수를 제어변수로 한 편상관분석 결과를 Table 4에 제시하였다. 상관분석 결과 담화 이해 점수는 구어 작업기억 중 숫 자 바로 따라 외우기와는 유의한 상관이 없었으나, 숫자 거꾸로 따 라 외우기, SVLT의 즉시회상, 지연회상, 재인점수와는 유의한 상관 을 보였다. 담화 이해 점수와 상관분석 결과 유의한 상관관계를 보 인 기억 과제의 수행을 표준점수(T점수)로 변환하여 나타낸 산포 도를 Figure 1에 제시하였다.

마지막으로 구어 작업기억과 언어기억 능력이 담화 이해 능력에 미치는 영향을 알아보기 위하여 중다회귀분석을 실시하였다. 회귀 분석 결과, 숫자 거꾸로 따라 외우기, SVLT의 즉시회상, 지연회상, 재인점수를 포함한 회귀모형은 유의한 것으로 나타났으며 $(F=6.711$, $p<.001)$, 담화 이해 능력을 예측하는 설명량은 약 $27.9 \%$ 였다.

\section{논의 및 결론}

본 연구에서는 이야기를 듣고 해당 질문에 답하는 회상 과제를
사용하여 담화 이해 능력과 고령자의 성별, 연령, 교육 정도 및 K$\mathrm{MMSE}$ 점수와의 관련성을 살펴보고, 담화 이해 능력과 구어 작업 기억 및 언어기억의 상관을 알아보는 것을 목적으로 하였다. 결과 를 살펴보면, 첫째, 담화 이해 점수에서 성별에 따른 차이는 나타나 지 않았으며, 남성과 여성 모두 담화 이해 점수와 연령, 교육년수 및 K-MMSE 점수의 상관은 유의하지 않았다. 둘째, 담화 이해 점수와 구어 작업기억 및 언어기억의 상관분석 결과 담화 이해 점수는 구 어 작업기억 중 숫자 바로 따라 외우기와는 유의한 상관이 없었으 나, 숫자 거꾸로 따라 외우기, SVLT의 즉시회상, 지연회상, 재인점수 에서 유의한 상관을 보였다. 마지막으로 구어 작업기억과 언어기억 능력이 담화 이해 능력에 미치는 영향을 알아보기 위하여 중다회 귀분석을 실시한 결과 숫자 거꾸로 따라 외우기, SVLT의 즉시회상, 지연회상, 재인점수를 포함한 회귀모형은 유의한 것으로 나타났다.

본 연구의 결과를 구체적으로 살펴보면, 우선 고령자의 담화 이 해 능력은 성별, 연령, 교육 정도 및 K-MMSE 점수에 영향을 받지 않는 것으로 나타났다. 이러한 결과는 일부의 연구결과와 일치한 다. Ferstl 등(2005)은 뇌손상이 없는 일반 고령자의 경우 담화 이해 능력은 연령, 교육년수, 성별에 의한 영향을 받지 않는다고 하였으 며, Mackenzie (2000) 또한 담화 이해 능력의 성별에 의한 차이는 없고, 최소한의 교육을 받은 경우 교육 정도에 의한 차이는 나타나 지 않는다고 하였다. 본 연구 대상자의 경우 교육년수가 평균 10 년 정도로 Mackenzie (2000)의 결과에서처럼 교육 정도에 의한 차이 가 없는 것으로 여겨진다. 다음으로 인지기능은 고령자의 담화 이 해 능력에 영향을 미칠 것으로 여겨지지만 본 연구에서는 고령자의 $\mathrm{K}-\mathrm{MMSE}$ 점수와 담화 이해 점수 사이에 유의한 상관이 나타나지 않았다. 그 이유는 K-MMSE 가 선별적인 수준의 인지기능 검사라 는 점과 본 연구의 대상자 모두 K-MMSE 점수가 정상 범위에 속하 는 고령자로 K-MMSE 점수의 표준편차가 불과 2점 미만이었다는 점 등을 들 수 있다. 또한, 본 연구에서 사용된 이야기 과제의 경우 어휘와 문장의 난이도가 담화 이해 과제의 수행에 미치는 영향을 최소화하기 위하여 고령자에게 친숙한 어휘와 문장만을 포함시켰 
기 때문에 성별, 연령, 교육 정도 및 K-MMSE 점수에 의한 영향이 배제되었을 가능성을 생각해볼 수 있다. 그러나, 담화 이해의 성별, 연령, 교육 정도 등의 영향은 사용된 담화 과제의 친숙도, 어휘의 난 이도, 문장의 구문적 복잡성 등에 따라 달라질 수 있으므로 결과 해석에 주의가 필요하다(Norman et al., 1991; Obler, Fein, Nicholas, \& Albert, 1991).

다음으로 담화 이해 점수와 구어 작업기억 및 언어기억의 상관 분석 결과 담화이해 점수는 구어 작업기억 중 숫자 바로 따라 외우 기 점수와는 유의한 상관이 없었지만, 숫자 거꾸로 따라 외우기, SVLT의 즉시회상, 지연회상, 재인점수에서 유의한 상관을 보였다. 우선, 청각적 언어처리와 구어 작업기억의 관련을 살펴보면, 구어 작업기억은 '단기 저장 시스템(temporary storage system)'과 시연 을 통해 정보를 유지하는 '조음 시스템(articulatory system)'으로 구성된 '음운루프(phonological loop)'에서 언어자극을 입력하고 '중앙집행기(central executive component)'에서 입력된 언어자극 을 조정하고 주의를 통제하는 등의 처리를 담당하게 된다(Baddeley, 2003). 본 연구에서는 고령자의 담화 이해 능력은 숫자 바로 따라 외우기와는 유의한 상관이 없었으나 숫자 거꾸로 따라 외우기 와는 유의한 상관이 나타나 기존의 연구 결과와 일치한다(Norman et al., 1991). 이렇듯 두 과제 사이에 상이한 결과가 나타난 이 유는 숫자 바로 따라 외우기와 숫자 거꾸로 따라 외우기 과제의 처 리과정 상의 차이로 설명할 수 있다. 숫자 바로 따라 외우기는 작업 기억의 구성요소 중 음운루프와 관련이 있으며, 이 음운루프의 역 할은 연속적으로 제시된 언어적 자극들의 활성화 상태를 일시적으 로 지속시키는 것이다. 반면, 입력된 언어자극들을 역순으로 따라 외우기 위해서는 음운루프 이외에 작업기억 중 중앙집행기의 역할 또한 요구된다(Hester, Kinsella, \& Ong, 2004). 담화 이해는 언어 자극의 저장 능력이 전제되어야 하지만 그 이외에 입력된 정보를 저 장하고, 통합하여 처리하는 과정을 거치게 되므로 저장 능력이 강 조된 숫자 바로 따라 외우기에 비해 저장 능력과 처리 능력이 동시 에 요구되는 숫자 거꾸로 따라 외우기 수행과의 상관이 높은 것으 로 생각해 볼 수 있다. 또한, 작업기억의 역할 중 일화적 장기기억 (episodic long term memory)과 같은 여러 자원에서 온 정보를 조 합하여 일관성 있는 일화로 엮어내는 '일화적 완충기(episodic buffer)'와 이를 통합하는 중앙집행기의 기능(Baddeley, 2000) 또한 담 화 이해와 관련이 있는 것으로 여겨진다.

노화로 인한 담화 이해 능력의 저하는 작업기억 중 저장기능의 저하와 관련이 있는 것으로 알려져 있다. 저장기능이 많이 요구되 는 과제의 경우 고령자의 수행저하가 두드러지게 나타나는데, 이러 한 저장기능의 비효율성은 결과적으로 처리기능의 할당량을 제한
시킨다(Light \& Albertson, 1988). 즉, 담화 이해 과제처럼 텍스트 안에서 관련 요소들을 연결해야 하는 고차원적인 처리과정을 요 구하는 과제에서는 활성화된 저장고(storage)에서 필요한 정보를 회상하는 과정에 더 많은 인지용량을 사용하기 때문에 처리과정 에 사용해야하는 할당량 또한 제한된다(Fischer \& Glanzer, 1986). 이러한 노화로 인한 작업기능 저하는 인지 처리 속도의 저하(Cohen, 1979), 비효율적으로 활성화된 비관련 정보의 억제기제 저하 (Hasher \& Zacks, 1988)와 관련된 것으로 알려져 있다.

다음으로 본 연구에서 고령자의 담화 이해 능력은 SVLT의 즉시 회상, 지연회상, 재인점수의 언어기억과 유의한 상관을 보였다.SVLT 는 3 회에 걸친 즉각회상 능력, 20 분 이후의 지연회상 능력, 재인 능 력을 평가하는 검사이다. 따라서 이 검사는 숫자 바로 따라 외우기 와 같은 기억의 일시적 저장 능력을 평가하는 검사이지만 단순히 청각적으로 입력되는 숫자를 보유하는 능력과 달리 복잡한 언어적 처리과정과 기억의 인지적 과정들을 포함한다(Woodruff-Pak \& Finkbiner, 1995). 이와 같은 이유로 언어기억 능력은 담화 이해 능 력과 관련이 있는 것으로 알려져 있다(Ferstl et al., 2005; Radvansky, 1999). 본 연구 결과 SVLT의 점수가 숫자 바로 따라 외우기 점 수와의 상관은 유의하지 않은 반면, 숫자 거꾸로 따라 외우기 점수 와는 유의한 상관을 보였다. 이는 언어기억이 단순한 기억 능력이 아닌 복합적인 언어적, 인지적 처리과정을 포함하고 있다는 것을 의 미한다. 또한, SVLT에서 사용된 단어들은 무작위로 선정된 단어가 아닌 범주별 단어들로 과제 수행 시 의미적 군집화(semantic clustering)와 같은 전략을 사용하는 것이 가능하다(Kim \& Kang, 1997). 따라서 언어기억의 수행이 높은 경우 효율적인 기억 능력을 가지고 있을 뿐 아니라, 그로 인해 처리과정에 더 많은 인지기능을 할당할 수 있어 청각적 담화 이해 과제의 수행이 높아진다고 설명할 수 있 다(Radvansky, 1999). 언어기억의 항목별 차이를 살펴보면 재인점 수가 즉시회상이나 지연회상보다 담화 이해 점수와 상대적으로 높 은 상관을 보였다. 이는 담화 이해의 질문유형 중에는 담화 내용을 직접적으로 대답하는 것(재인+회상)뿐만 아니라 담화의 내용 중 담화의 의미(재인)를 과거의 지식과 통합하여 설명해야 하는 추론 유형이 포함되어 있기 때문에 재인 능력의 요구가 더 크기 때문인 것으로 여겨진다.

또한, 담화 이해력과 언어기억 간의 관련성은 서론에서 설명한 담화 이해의 단계적 측면과 연결지어 설명할 수 있다. 담화 이해의 단계적 측면과 노화로 인한 영향을 살펴보면, 표면 구조 및 명제적 추상성과 관련된 기억은 세부항목(detail)에 대한 기억으로 젊은이 들에 비해 고령자에게서 어려움이 나타난다(Kemper, 1987). 그러나 상황 모형에 기반한 처리과정은 노화로 인한 영향을 받지 않는 것 
으로 알려져 있다(Radvansky, Zacks, \& Hasher, 1996). 따라서 노화 로 인한 담화 이해의 어려움은 기억 능력의 손상에 기인하며(Stien \& Wingfield, 1988), 본 연구의 과제와 같이 회상 요구가 높은 과제 의 경우 고령자의 수행이 저하되고(Zacks, 1989), 일반 지식을 이용 한 추론과 같이 기억 능력의 요구가 상대적으로 적은 과제의 경우 노화로 인한 영향은 거의 없는 것으로 알려져 있다(Belmore, 1981). 마지막으로 구어 작업기억과 언어기억 능력이 담화 이해 능력에 미치는 영향을 분석한 결과 숫자 거꾸로 따라 외우기, SVLT의 즉시 회상, 지연회상, 재인점수를 포함한 회귀모형은 담화 이해력을 유의 하게 예측하는 것으로 나타났다. 이렇듯 담화 이해 능력은 다양한 구어 기억능력과 관련을 가지며, 단기기억, 작업기억, 장기기억 모두 를 요구한다(Trabasso \& Magliano, 1996). 그러나 담화 이해 능력 은 기억 능력 이외에서 다양한 인지기능의 영향을 받는다. Ferstl 등 (2005)은 담화 이해에 요구되는 다양한 인지처리 과정을 설명하였 는데, 이를 종합하면 언어적 처리과정을 사용한 메시지의 등록(decoding), 청각적 이해과정 동안의 주의유지(attention), 연속적인 발 화를 듣고 내용을 저장하기 위한 구어 작업기억, 주어진 텍스트의 내용을 장기기억의 표상으로 전환시키는 언어학습, 정보를 구조화 하고 이해의 과정을 모니터링하는 집행기능(executive function) 등 을 포함한다. 따라서 본 연구에서 살펴본 구어 기억 능력 이외에도 다양한 담화 이해에 영향을 미치는 다양한 인지기능에 관련된 연 구가 이루어져야 할 것이다.

본 연구는 고령자의 일상생활에서의 의사소통 상황을 적절히 반 영한 회상 과제를 사용하여 고령자의 담화 이해 능력을 살펴보고 이러한 담화 이해 능력이 고령자의 구어 작업기억 및 언어기억과 어 떠한 관련성이 있는지를 살펴보았다. 본 연구의 결과는 고령자의 의사소통 특성을 파악하여 언어 및 의사소통장애를 가진 고령자 의 담화 이해 능력 평가의 규준으로 삼고, 적절한 재활 프로그램을 개발하기 위한 기초자료로 활용이 가능하다는 점에서 임상적인 의 의를 가진다. 다만, 청년층과의 담화 이해 능력을 비교하여 노화로 인한 차이를 구체적으로 밝히지 못한 점, 사용된 담화 이해 과제의 단편성 등이 아쉬움으로 남는다. 앞으로는 보다 다양한 과제를 사 용한 고령자 및 신경언어장애 환자군의 담화 이해 연구가 진행되기 를 기대해 본다.

\section{REFERENCES}

Baddeley, A., \& Hitch, G. J. (1974). Working memory. Psychology of Learning and Motivation, 8, 47-89.

Baddeley, A. (1986). Working memory. Oxford, UK: Oxford University Press.
Baddeley, A. (2000). The episodic buffer: a new component of working memory? Trends in Cognitive Sciences, 4, 417-423.

Baddeley, A. (2003). Working memory and language: an overview. Journal of Communication Disorders, 36, 189-208.

Baltes, P. B., \& Lindenberger, U. (1997). Emergence of a powerful connection between sensory and cognitive functions across the adult life span: a new window to the study of cognitive aging? Psychology and Aging, 12, 12-21.

Belmore, S. M. (1981). Age-related changes in processing explicit and implicit language. Journal of Gerontology, 36, 316-322.

Borod, J. C., Goodglass, H., \& Kaplan, E. (1980). Normative data on the Boston diagnostic aphasia examination, parietal lobe battery, and the Boston naming test. Journal of Clinical Neuropsychology, 2, 209-215.

Bowles, N. L., \& Poon, L. W. (1985). Aging and retrieval of words in semantic memory. Journal of Gerontology, 40, 71-77.

Burke, D. M., MacKay, D. G., \& James, L. E. (2000). Theoretical approaches to language and aging. In T. Perfect \& E. Maylor (Eds.), Models of cognitive aging (pp. 204-237). Oxford, UK: Oxford University Press.

Cain, K., \& Oakhill, J. V. (1999). Inference making ability and its relation to comprehension failure in young children. Reading and Writing, 11, 489-503.

Caplan, D., \& Evans, K. L. (1990). The effects of syntactic structure on discourse comprehension in patients with parsing impairments. Brain and Language, 39, 206-234.

Carpenter, P. A., Miyake, A., \& Just, M. A. (1994). Working memory constraints in comprehension: evidence from individual differences, aphasia, and aging. In M. A. Gernsbacher (Ed.), Handbook of psycholinguistics (pp. 10751122). San Diego, CA: Academic Press.

Choi, C. S., \& Choi, H. J. (2013). Story comprehension ability in patients with MCI and DAT. Korean Journal of Speech and Hearing Disorders, 22, 159-180.

Cohen, G. (1979). Language comprehension in old age. Cognitive Psychology, $11,412-429$.

Daneman, M., \& Carpenter, P. A. (1980). Individual differences in working memory and reading. Journal of Verbal Learning and Verbal Behavior, 19, 450-466.

Daneman, M., \& Merikle, P. M. (1996). Working memory and language comprehension: a meta-analysis. Psychonomic Bulletin and Review, 3, 422-433.

Ferstl, E. C., Walther, K., Guthke, T., \& von Cramon, D. Y. (2005). Assessment of story comprehension deficits after brain damage. Journal of Clinical and Experimental Neuropsychology, 27, 367-384.

Fischer, B., \& Glanzer, M. (1986). Short-term storage and the processing of cohesion during reading. Quarterly Journal of Experimental Psychology, 
$38,431-460$.

Hasher, L., \& Zacks, R. T. (1988). Working memory, comprehension, and aging: a review and a new view. Psychology of Learning and Motivation, 22, 193-225.

Hester, R. L., Kinsella, G. J., \& Ong, B. (2004). Effect of age on forward and backward span tasks. Journal of the International Neuropsychological Society, 10, 475-481.

Hummert, M. L., Garstka, T. A., Ryan, E. B., \& Bonnesen, J. L. (2004). The role of age stereotypes in interpersonal communication. In J. F. Nussbaum \& J. Coupland (Eds.), Handbook of communication and aging research (2nd ed., pp. 91-114). Mahwah, NJ: Lawrence Erlbaum Associates.

Just, M. A., \& Carpenter, P. A. (1980). A theory of reading: from eye fixations to comprehension. Psychological Review, 4, 329-354.

Just, M. A., \& Carpenter, P. A. (1987). The psychology of reading and language comprehension. Boston, MA: Allyn \& Bacon.

Kang, Y. W. (2006). A normative study of the Korean-Mini Mental State Examination (K-MMSE) in the elderly. Korean Journal of Psychology, 25, 1-12.

Kang, Y. W., \& Na, D. L. (2003). Seoul Verbal Learning Test (SVLT). Seoul: Human Brain Research and Consulting Co.

Kang, Y., Chin, J., \& Na, D. L. (2002). A normative study of the Digit Span Test for the elderly. Korean Journal of Clinical Psychology, 21, 911-922.

Kemper, S. (1987). Syntactic complexity and elderly adults' prose recall. Experimental Aging Research, 13, 47-52.

Kim, J. K., \& Kang, Y. (1997). Korean-California Verbal Learning Test (K-CVLT): a normative study. Korean Journal of Clinical Psychology, 16, 379-395.

Light, L. L., \& Albertson, S. A. (1988). Comprehension of pragmatic implications in young and older adults. Language, Memory, and Aging, 8, 133-153.

Mackenzie, C. (2000). The relevance of education and age in the assessment of discourse comprehension. Clinical Linguistics and Phonetics, 14, 151-161.

Norbury, C. F., \& Bishop, D. V. M. (2002). Inferential processing and story recall in children with communication problems: a comparison of specific language impairment, pragmatic language impairment and high-functioning autism. International Journal of Language and Communication Disorders, 37, 227-251.

Norman, S., Kemper, S., Kynette, D., Hintat, C., \& Anagnopoulous, C. (1991). Syntactic complexity and adults' running memory span. Journal of Gerontology: Psychological Sciences, 46, 346-351.

Obler, L. K., Fein, D., Nicholas, M., \& Albert, M. L. (1991). Auditory comprehension and aging: decline in syntactic processing. Applied Psycholinguistics, $12,433-452$.
Perfetti, C. A., \& Goldman, S. R. (1976). Discourse memory and reading comprehension skill. Journal of Verbal Learning and Verbal Behavior, 15, 33-42. Radvansky, G. A. (1999). Aging, memory, and comprehension. Current Directions in Psychological Science, 8, 49-53.

Radvansky, G. A., \& Curiel, J. M. (1998). Narrative comprehension and aging: the fate of completed goal information. Psychology and Aging, 13, 6979.

Radvansky, G. A., Zacks, R. T., \& Hasher, L. (1996). Fact retrieval in younger and older adults: the role of mental models. Psychology and Aging, 11, 258271.

Salthouse, T. A. (1996). Constraints on theories of cognitive aging. Psychology and Aging, 3, 287-299.

Sparks, J. R., \& Rapp, D. N. (2010). Discourse processing: examining our everyday language experiences. Wiley Interdisciplinary Reviews: Cognitive Science, 1, 371-381.

Stine, E. L., \& Wingfield, A. (1988). Memorability functions as an indicator of qualitative age differences in text recall. Psychology and Aging, 3, 179-183.

Thornton, R., \& Light, L. L. (2006). Language comprehension and production in normal aging. In J. E. Birren et al. (Eds.), Handbook of the psychology of aging (6th ed., pp. 261-287). San Diego, CA: Academic Press.

Trabasso, T., \& Magliano, J. P. (1996). Conscious understanding during comprehension. Discourse Processes, 21, 255-287.

Waters, G., \& Caplan, D. (2005). The relationship between age, processing speed, working memory capacity, and language comprehension. Memory, $13,403-413$.

Welland, R. J., Lubinski, R., \& Higginbotham, D. J. (2002). Discourse comprehension test performance of elders with dementia of the Alzheimer type. Journal of Speech, Language, and Hearing Research, 45, 1175.

Woodruff-Pak, D. S., \& Finkbiner, R. G. (1995). Larger nondeclarative than declarative deficits in learning and memory in human aging. Psychology and Aging, 10, 416.

Yun, H. R., \& Kim, Y. T. (2005). Story comprehension abilities in school-age children with specific language impairment. Korean Journal of Communication Disorders, 10, 41-56.

Zacks, R. T. (1989). Working memory, comprehension, and aging: a review and a new view. Psychology of Learning and Motivation, 22, 193-225.

Zacks, R., \& Hasher, L. (1997). Cognitive gerontology and attentional inhibition: a reply to Burke and McDowd. Journals of Gerontology Series B: Psychological Sciences and Social Sciences, 52, 274-283. 
Appendix 1. 질문유형의 예

\begin{tabular}{lcc}
\hline 질문유형 & 질문 & 정답 \\
\hline 사실적 정보이해 & 뚝배기 안에서 무엇이 나왔나요? & 파리 \\
텍스트 연결 추론 & 두 할아버지는 왜 한국식당에 가기로 결정했나요? & 기집이 삼계탕 맛있기로 소문이 나서 \\
빠진 정보 추론 & 이 이야기의 계절은 언제라고 생각하세요? & 여름 \\
\hline
\end{tabular}




\section{국문초록}

\section{고령자의 담화 이해 능력과 구어 작업기억 및 언어기억과의 상관}

최현주

나사렛대학교 언어치료학과

배경 및 목적: 고령자의 담화 이해 능력은 실제적인 의사소통 능력을 반영하며, 다양한 인지기능과 관련을 가진다. 본 연구는 이야기를 듣고 질문에 답하는 담화 이해 과제를 사용하여 고령자의 성별, 연령, 교육년수 및 K-MMSE 점수가 담화 이해 능력에 미치는 영향을 살 펴보고, 구어 작업기억 및 언어기억과 담화 이해 능력의 상관을 알아보는 것을 목적으로 하였다. 방법: 본 연구는 일반 고령자 60명(남 성 30 명, 여성 30 명)을 대상으로 하였다. 담화 이해 과제는 청각적으로 제시되는 이야기를 듣고 질문에 답하도록 하는 이야기 이해 과제 를 사용하였다. 구어 작업기억 과제로 숫자 외우기(Digit Span Test)를, 언어기억 과제로 서울언어학습검사(SVLT)를 사용하였다. 결과: 첫째, 성별, 연령, 교육년수 및 K-MMSE점수는 고령자의 담화 이해 능력에 영향을 미치지 않는 것으로 나타났다. 둘째, 상관분석 결과 담화 이해 점수는 구어 작업기억 중 숫자 거꾸로 따라 외우기와 SVLT의 모든 항목과 유의한 상관을 보였다. 셋째, 중다회귀분석 결과 숫자 거꾸로 따라 외우기와 SVLT점수가 담화 이해 능력을 유의하게 설명하는 것으로 나타났다. 논의 및 결론: 이와 같은 결과로부터 담화 이해 능력은 다양한 기억 능력과 관련이 있음을 알 수 있다. 또한, 본 연구의 결과는 다양한 신경언어장애군의 담화 이해 평가 및 치료를 위한 기초 자료로 활용할 수 있다.

핵심어: 담화 이해, 구어 작업기억, 언어기억

본 연구는 2014년도 나사렛대학교 교내연구비 지원으로 이루어졌음.

\section{참고문헌}

강연욱(2006). K-MMSE (Korean-Mini Mental State Examination)의 노인 규준 연구. 한국심리학회지, 25, 1-12.

강연욱, 나덕렬(2003). 서울언어학습검사(SVLT). 서울: 휴브알엔씨.

강연욱, 진주희, 나덕렬(2002). 숫자 외우기 검사(Digit Span Test)의 노인 규준 연구. 한국심리학회지: 임상, 21, 911-922.

김정기, 강연욱(1997). 한국판 캘리포니아 언어학습검사(K-CVLT)의 표준화 연구. 한국심리학회지: 임상, 16, 379-395.

윤혜련, 김영태(2005). 학령기 단순언어장애아동의 이야기 이해특성. 언어청각장애연구, 10, 41-56.

최창선, 최현주(2013). 경도인지장애와 알츠하이머형 치매 환자의 이야기 이해 특성. 언어치료연구, 22, 159-180. 